\title{
Do Aquatic Macrophytes Configuration Mode Impact Water Quality?
} (Adakah Mod Konfigurasi Akua Makrofit Mengesan Kualiti Air?)

\author{
HUI-HUI WANG, Jing-LAN LiU, Rong ZHANG, JiA-KAI LiU, YU-Qi Zou \& ZHEN-Ming ZHANG*
}

\begin{abstract}
This paper had selected watermifoil (Myriophyllum veticillatum Linn.), softstem bulrush (Scirpus validus Vahl) and yellow-flowered iris (Iris wilsonii), in showing the water purification through different configuration. AFIs with different combination of aquatic plants were set up to purify the water quality for 50 days. This paper aimed to evaluate chemical and vegetative characteristics of each type of plant and also to find configuration of aquatic plants to maximize the contaminants removal efficiency by artificial floating island (AFI). The result indicated that the trophic waterbody promote the growth of plants and all of the AFIs have the ability to purify water and reduce contaminants. However, the most effective way is by combination of these three aquatic plants which has strong capacity to remove $\mathrm{COD}, \mathrm{NO}_{3}$, total nitrogen, total phosphorous and improve pH levels. Watermifoil (Myriophyllum verticillatum Linn.) is better than yellow-flowered iris (Iris wilsonii) and softstem bulrush (Scirpus validus Vahl) in disposing water pollutants.
\end{abstract}

Keywords: Aquatic plants; configuration; water purification

\section{ABSTRAK}

Kertas ini telah memilih tumbuhan watermifoil (Myriophyllum veticillatum Linn.), softstem bulrush (Scirpus validus Vahl) dan yellow-flowered iris (Iris wilsonii) yang menulenkan air melalui konfigurasi berbeza. AFI dengan kombinasi berbeza tumbuhan akuatik disediakan bagi menulenkan air selama 50 hari. Kajian ini bertujuan menilai ciri kimia dan vegetatif setiap tumbuhan yang dikaji di samping mencari konfigurasi tumbuhan akuatik bagi memaksimumkan kecekapan penyingkiran bahan cemar melalui pulau terapung buatan (AFI). Keputusan kajian menunjukkan jasad air trofik menggalakkan pertumbuhan tumbuhan dan semua kombinasi AFI berupaya untuk menulenkan air dan mengurangkan bahan cemar. Kombinasi yang paling berkesan adalah kombinasi ketiga-tiga tumbuhan kerana mempunyai kapasiti yang tinggi untuk menyingkirkan $\mathrm{COD}, \mathrm{NO}_{3}^{-}$, jumlah nitrogen, jumlah fosforus dan memperbaiki aras $\mathrm{pH}$. Watermifoil (Myriophyllum verticillatum Linn.) adalah lebih baik berbanding yellow-flowered iris (Iris wilsonii) untuk digabungkan dengan softstem bulrush (Scirpus validus Vahl) dalam menyingkirkan bahan cemar.

Kata kunci: Konfigurasi; penulenan air; tumbuhan akuatik

\section{INTRODUCTION}

The main objective in wastewater treatment process is to eliminate or reduce contaminants to the level that cause no adverse effect on human or the receiving environment (Okia 1993). Various conventional methods are in practice for purification of water and removing eutrophic water. Many traditional approaches are non-eco-friendly, timeconsuming and expensive. Artificial floating island (AFI) is an efficient and eco-friendly way to purify the water quality. It relies on nature process to mechanically and biologically filter water as it passes slowly through shallow areas of dense aquatic vegetation, and through permeable bottom soil (Stewart et al. 2008).

Nakamura and Mueller (2008) reported water quality enhancement is the most important feature of AFI, especially in Asia where their installation over large surface areas (10 to $30 \%$ ) of lakes and reservoirs help mitigate the effects of eutrophication. De Stefani et al. (2011) developed an experiment which was conducted in a channel receiving aquaculture effluents and found that median chemical oxygen demand (COD) in water passing through the floating wetland system was reduced by $66 \%$, biochemical oxygen demand by $52 \%$ and total phosphorus by $65 \%$. Zhao et al. (2012) indicated that average removal rates for total nitrogen $(\mathrm{TN}), \mathrm{NH}^{4+}-\mathrm{N}, \mathrm{NO}^{3-}-\mathrm{N} \mathrm{NO}^{2-}-\mathrm{N}$, total phosphorus (TP) and chlorophyll a in summer-autumn season were $36.9 \%, 44.8 \%, 25.6 \%, 53.2 \%, 43.3 \%$ and $64.5 \%$. In addition, it also effectively reduced the concentrations of total suspended substance (TSS), Escherichia coli and heavy metals.

Aquatic plants are essential for getting the good ecological status of aquatic ecosystems, and it is therefore necessary to preserve such communities in freshwaters (Bornette \& Puijalon 2011). Aquatic plants are suitable for wastewater treatment because they have tremendous capacity of absorbing nutrients and other substances from the water (Boyd 1970) and hence bring the pollution load down. Macrophytes play key functions in biochemical cycles, through, for example, organic carbon production, phosphorous mobilisation and the transfer of other trace 
elements (Jeppesen et al. 1998; Murphy 2002). Zhu et al. (2011) studied seven species, especially Salix babylonica, Gypsophila sp. whereby Oenanthe javanica had an ideal effect on TN and TP removal and could be widely utilized for the treatment of wastewater in rural areas. Nakai et al. (2010) found that $T$.angustifolia, S.tabernaemontani and $P$. australis have the potential beneficial species for vegetation on artificial floating islands. These species may enhance the water purification owing to anti-cyanobacterial allelopathic effects. Elankumaran et al. (2003) established a comparative study between Hydrilla verticillata and Salvinia sp. and concluded that removal efficiency of Hydrilla verticillata is higher in lower concentration of (at $5 \mathrm{ppm}$ ) compared to Salvinia, but in higher concentration removal efficiency of Salvinia is more. Juwarkar et al. (1995) have reported $78 \%$ to $91 \%$ removal of BOD, nitrogen reduction from 30.8 to $9.8 \mathrm{mg} / \mathrm{L}$ and phosphate reduction from 14.9 to $9.6 \mathrm{mg} / \mathrm{L}$ using the emergent macrophytes Typha latiofolia and Phragmites carka. According to Dunabin and Bowmer (1992) these emergent plants influence metal storage indirectly by modifying the substratum through oxygenation, buffering and $\mathrm{pH}$ and adding organic matter. $\mathrm{Hu}$ et al. (2010) also reported plant eco-island system had remarkable purification ability to remove pollutants from hypereutrophic water and mixed planting of $O$. javanica D.C. with $N$. officinale on the FEIS may enhance nutrient removal and water quality improvement of eutrophic water bodies, especially at low temperature season. Yao et al. (2011) also reported that AFI with plants had a strong capacity for the removal of nitrogen and phosphorus. In particular, softstem bulrush (S. validus Vahl) and spiked loosestrife (L. salicaria Linn.) were excellent aquatic plants in Beijing wetland restoration.

Until recently, we only selected certain aquatic plants which have efficient removal rate. There is some lake of knowledge about configuration of aquatic plants. While in the current study, AFIs with different combination of aquatic plants were used to do the reaserch. The aims were to find the best optional floating island configuration to enhance the water quality; find the best plant or combination to match with softstem bulrush (Scirpus validus Vahl) and confirm a floating island which is qualify enough to dispose the pollutants and provide scientific evidence for ecological restoration in Beijing.

\section{METERIALS AND METHODS}

\section{EXPERIMENTAL MATERIALS}

Three kinds of plants were selected in this experiment and they are watermifoil (Myriophyllum veticillatum Linn.), softstem bulrush (Scirpus validus Vahl) and yellowflowered iris (Iris wilsonii), respectively.

\section{EXPERIMENTAL DESIGN}

Four kinds of AFI were made, three of these all contain softstem bulrush (S. validus Vahl). They were assembled with watermifoil (M. veticillatum Linn.), yellow-flowered iris (I. wilsonii), the combination of watermifoil $(M$. veticillatum Linn.) and yellow-flowered iris (I.wilsonii), respectively. The last AFI was only substrate without any vegetation, thus acting as a control experiment (Table 1). The total number of the whole experiment was twenty water jars and each type consisted of five same groups of repeated trial marked A, B, C, D and E. Only in this way, the data integrity and accuracy can be guaranteed.

\section{DATA MEASUREMENTS}

pH levels, chemical oxygen demand (COD), nitrate, total nitrogen (TN) and total phosphorous (TP) was measured in each water jar at the begin of the experiment. At 10-day intervals, the chemical parameters were measured again. SPSS 13.0 and Sigmaplot 10.0 software were used to process data. Moreover, the biomass at the initiation and completion of the experiment were also measured.

\section{RESULTS}

\section{PLANT GROWTH}

The growth characteristics of the plant species after 50 days of growth on the AFI is presented in Figure 1. All the species had a similar amount of aboveground biomass (12.58 to $14.25 \mathrm{~g}$ ) at the end of the study. The configuration of these three plants had the greatest amount of aboveground biomass (14.25 g), followed by the configuration of Softstem bulrush (S. validus Vahl) and watermifoil (M. verticillatum Linn.) (13 g). The configuration of yellow-flowered iris ( $I$. wilsonii) and Softstem bulrush (S. validus Vahl) had the least aboveground biomass (12.58 g). The configurations of these plants also had the greatest amount of underground biomass $(14.21 \mathrm{~g})$, followed by the configurations of yellow-flowered iris (I. wilsonii) and Softstem bulrush (S. validus Vahl) (14.08 g). The configuration of Softstem bulrush (S. validus Vahl) and watermifoil (M. verticillatum Linn.) had the smallest underground biomass (8.4 g) of the three configurations.

The four vegetations therefore showed excellent growth in AFI, with extensive development of roots beneath the water (Figure 1). The scope of root length for the three experimental configurations was between 24.58 and 30.14 $\mathrm{cm}$, with minimum depths of up to $24.58 \mathrm{~cm}$ recorded for the configuration of Softstem bulrush (S. validus Vahl) and watermifoil (M. verticillatum Linn.). In contrast, yellowflowered iris (I.wilsonii) and Softstem bulrush (S. validus Vahl) had the longest roots, the majority of which were more than $30.14 \mathrm{~cm}$. The height of the configurations of these plants ranged from 89.25 to $108.25 \mathrm{~cm}$. The configuration of Softstem bulrush ( $S$. validus Vahl) and watermifoil ( $M$. verticillatum Linn.) are the highest $(108.25 \mathrm{~g})$, followed by the configuration of these three plants $(90.15 \mathrm{~g})$. The value of configurations of yellow-flowered iris (I. wilsonii) and Softstem bulrush (S. validus Vahl) (89.25 g) are very close to the value of these three plants' configuration. 
TABLE 1. Schematic representation of the experimental design

\begin{tabular}{llll}
\hline A1 & B1 & C1 & D1 \\
A2 & B2 & C2 & D2 \\
A3 & B3 & C3 & D3 \\
A4 & B4 & C4 & D4 \\
A5 & B5 & C5 & D5 \\
\hline
\end{tabular}

A = AFI; B = AFI with softstem bulrush (Scirpus validus Vahl) and watermifoil (Myriophyllum veticillatum Linn.); $\mathrm{C}=$ AFI with softstem bulrush (Scirpus validus Vahl) and yellow-flowered iris(Iris wilsonii) and D = AFI with softstem bulrush (Scirpus validus Vahl), watermifoil (Myriophyllum veticillatum Linn.) and yellowflowered iris (Iris wilsonii). A1 to A5, B1 to B5, C1 to C5 and D1 to D5 are the five duplicated experiments for data analysis
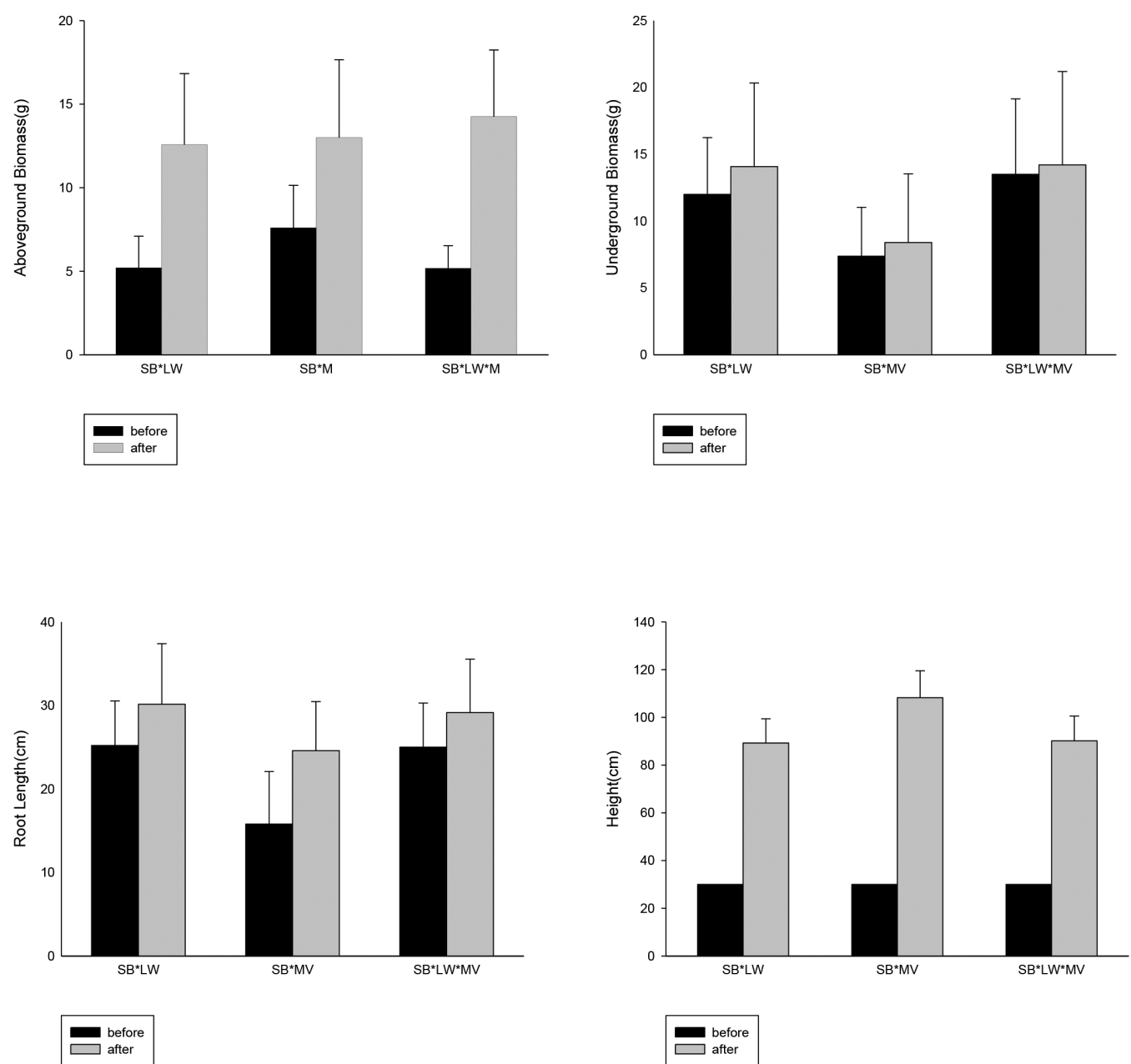

FIGURE 1. Growth characteristics of three different configurations measured in June 2011 after 50 days growth. Values in parentheses are standard deviations

SB=Softstem bulrush (Scirpus validus Vahl), LW=yellow-flowered iris (Iris wilsonii), MV=watermifoil (Myriophyllum verticillatum Linn.)

\section{WATER QUALITY EFFECTS}

Figure 2 shows the graphs for mean concentrations for

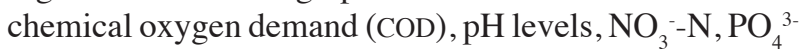
-P total nitrogen (TN), total phosphorus (TP) and for each treatment throughout the batches.

\section{CHEMICAL OXYGEN DEMAND (COD)}

The top left graph illustrated AFI without vegetation rose and fell dramatically on 20th June to 20th July, went up from 38.15 to $58.9 \mathrm{mg} / \mathrm{L}$ and then descended to $36.43 \mathrm{mg} / \mathrm{L}$ and it went up again to $45.97 \mathrm{mg} / \mathrm{L}$ and then descended until turns out to be flat in the end $(42.4 \mathrm{mg} / \mathrm{L})$. While the rest of the three groups decrease modestly, the configurations of yellow-flowered iris (I. wilsonii) and Softstem bulrush (S. validus Vahl) had the greatest amount of COD (22.36 $\mathrm{mg} / \mathrm{L})$, followed the configuration of Softstem bulrush (S. validus Vahl) and watermifoil (M. verticillatum Linn.) $(15.25 \mathrm{mg} / \mathrm{L})$. The configuration of these three aquatic plants had lest amount of COD $(10.25 \mathrm{mg} / \mathrm{L})$. 


\section{pH LEVELS}

A measure of the acidity or alkalinity of a solution was reflected by the $\mathrm{pH}$ value as shown on the top right graph. AFIs without plants showed a trend of ascending $\mathrm{pH}$ from the beginning $(\mathrm{pH}=8.4)$ to the end $(\mathrm{pH}=9.90)$ (Figure 2). After 50 days, AFI with yellow-flowered iris (I. wilsonii) and softstem bulrush (S. validus Vahl), AFI with softstem bulrush (S. validus Vahl) and watermifoil (M.verticillatum Linn.) and AFI with these three aquatic plants presented a wave trend from 8.4 to $8.54,8.4$ to $8.45,8.49$ to 8.11 and 8.49 to 8.64 , respectively.

\section{$\mathrm{NO}_{3}^{-}$CONCENTRATION}

The middle left graph illustrated the reduction process of the $\mathrm{NO}_{3}{ }^{-}$. The curve of the AFI without vegetation came up to the summit $(2.59 \mathrm{mg} / \mathrm{L})$ in the third measurement and then fell in the end noticeably. The other three curves declined obviously. Starting at the same point (1.29 mg/L), the values of AFI with yellow-flowered iris (I. wilsonii) and Softstem bulrush (S. validus Vahl), the configuration of softstem bulrush ( $S$. validus Vahl) and watermifoil ( $M$. verticillatum Linn.) and AFI with these three aquatic plants dropped to $0.15,0.08$ and $0.05 \mathrm{mg} / \mathrm{L}$. If we concentrate on the initial and final data, no more than one curve of AFI with these three aquatic plants decreases to below $0.05 \mathrm{mg} / \mathrm{L}$.

$$
\mathrm{PO}_{4}^{3-}
$$

AFIs without plants went up from $1.35 \mathrm{mg} / \mathrm{L}$ separately to $1.68 \mathrm{mg} / \mathrm{L}$ and then descended ultimately (Figure 2 ). In addition, the other four experiments overall tend descended. All the configuration had a similar amount of $\mathrm{PO}_{4}^{3-}(0.08$ to $0.1 \mathrm{mg} / \mathrm{L})$ at the end of the study as shown on middle right graph. AFI with yellow-flowered iris ( $I$. wilsonii) and softstem bulrush (S. validus Vahl) had the greatest amount of $\mathrm{PO}_{4}^{3-}(0.1 \mathrm{mg} / \mathrm{L})$, followed AFI with these three aquatic plants $(0.09 \mathrm{mg} / \mathrm{L})$. The configuration of softstem bulrush (S. validus Vahl) and watermifoil ( $M$. verticillatum Linn.) had lest amount of $\mathrm{PO}_{4}^{3-}(0.08 \mathrm{mg} / \mathrm{L})$. Total nitrogen $(\mathrm{TN})$

Bottom left graph illustrated a reduction process of the total nitrogen. AFIs without plants fluctuate greatly. It went up from $2.75 \mathrm{mg} / \mathrm{L}$ separately to $3.62 \mathrm{mg} / \mathrm{L}$ and then descended to $2.24 \mathrm{mg} / \mathrm{L}$. AFI with yellow-flowered iris ( $I$. wilsonii) and softstem bulrush (S. validus Vahl), AFI with Softstem bulrush (S. validus Vahl) and watermifoil ( $M$. verticillatum Linn.) and AFI with these three aquatic plants showed evenly declining trends from 2.75 to $0.82,2.75$ to 0.78 and 2.75 to 0.70 , respectively. If we concentrate on the initial and final data, no more than one curve of AFI with these three aquatic plants decreases to below 0.75 $\mathrm{mg} / \mathrm{L}(0.70 \mathrm{mg} / \mathrm{L})$.

\section{TOTAL PHOSPHOROUS (TP)}

The bottom right graph illustrated the reduction process of the total phosphorous. AFI without vegetation ascended slightly in the first and second sampling. In detail, they rose from 0.49 to $0.60 \mathrm{mg} / \mathrm{L}$ and then kept steady declining trends. AFI with yellow-flowered iris (I. wilsonii) and softstem bulrush ( $S$. validus Vahl), AFI with Softstem bulrush (S. validus Vahl) and watermifoil (M.verticillatum Linn.) and AFI with these three aquatic plants showed evenly trends of decling from 0.49 to $0.07,0.49$ to 0.06 and 0.49 to 0.05 , respectively. Obviously AFI with these three aquatic plants had lest amount of Total phosphorous.

\section{DISCUSSION}

The AFI stocks nutrients inside the aquatic plants and base meterials. The trophic condition of the waterbody promotes the growth of plants. It seems there is a proportional relation between the biomass and the nutrients in the water. Phosphorous and nitrogen are both key parameters for aquatic plant life. The ammonium ion is the preferred nitrogen source for plant growth (James et al. 2004; Smolders et al. 2002). The capacity to absorb COD, $\mathrm{NO}_{3}^{-}$, total nitrogen and total phosphorous of AFI with these three aquatic plants was better than other aquatic plants. Therefore, the configuration of these three plants had the greatest change value of aboveground biomass. In contrast to aboveground biomass, length of roots and underground biomass of AFI with these three aquatic plants reach the least change value. On the other hand, non-rooted macrophytes absorb their nutrients from water, and are consequently usually found in aquatic ecosystems where the nutrient level in the water column is high (Lacoul \& Freedman 2006). In addition, rooted plants can use nutrients both in the water column and in the substrate (Madsen \& Cedergreen 2002). Watermifoil (M.verticillatum Linn.) is a kind of submerged plant. It almost do not have any roots let alone underground biomass. Denny (1980) observed that tendency to use shoots as sites of heavy metal uptake instead of roots increases with progression towards submergence and simplicity of shoot structure.

Some other researches also illustrated the water purification characteristics of the aquatic plants, especially softstem bulrush (S. validus). Hunter et al. (2001) had demonstrated the importance of softstem bulrush $(S$. validus), an obligate wetland plant that is used regularly in wetlands for wastewater treatment, on removal of ammonium, orthophosphate and total organic carbon (TOC) from microcosms receiving synthetic municipal wastewater. Average percent removal of $\mathrm{NH}^{4+}-\mathrm{N}$ was significantly greater in microcosms containing plants $(67 \%)$ than in those without plants $(29 \%)$. Percent removal of $\mathrm{PO}_{4}^{3-}-\mathrm{P}$ was also significantly greater in microcosms with plants $(42 \%)$ than in microcosms without plants (20\%). Yao (2011) had showed the capacity of degradation of phosphorous by AFI with spiked loosestrife (L. salicaria Linn.) was better than others AFI with vegetation, while the capacity of removal nitrogen of AFI with softstem bulrush (S. validus Vahl) was better than others. This means that the AFI with the plants has big potential as a nutrient stock room. Gersberg et al. (1986) demonstrated investigations using artificial wetlands which quantitatively assess the 

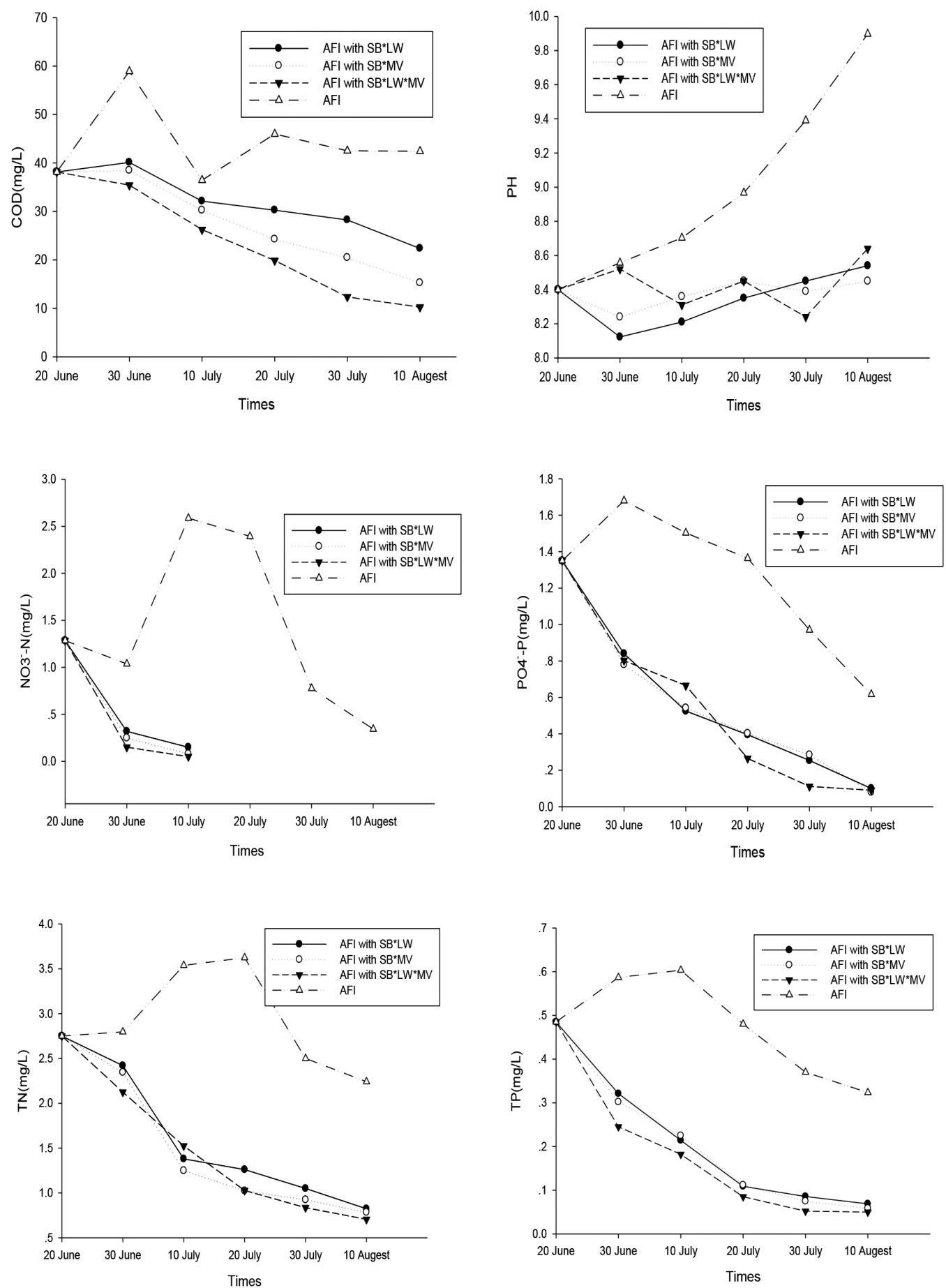

FIGURE 2. Mean concentration for PH, COD, PO43-P, NO3-N, TN, TP, for each treatment throughout the batches $(n=5)$. Initial concentrations ( $\left.\mathrm{PH}, \mathrm{COD}, \mathrm{PO}_{4}{ }^{3}-\mathrm{P}, \mathrm{NO}_{3}-\mathrm{N}, \mathrm{TN}, \mathrm{TP}\right)$ are 8.4,38.15, 1.35, 1.285, 2.75 and $0.485 \mathrm{mg} / \mathrm{L}$. Error bars represent +/-one standard error of the mean. Fifty days samples were only collected for some treatments (SB, LW and MV)

role of each of three higher aquatic plant types, Scirpus validus, Phragmites communis and Typha latifola, in the removal of nitrogen, BOD and TSS from primary municipal wastewaters. During the period August 1983-December 1984 , the mean ammonia concentration of $24.7 \mathrm{mg} \mathrm{l}^{-1}$ in the primary wastewater inflow (hydraulic application rate $=4.7 \mathrm{~cm} \mathrm{day}^{-1}$ ) was reduced to mean effluent levels of $1.4 \mathrm{mg}^{-1}$ for the bulrush bed, $5.3 \mathrm{mg} \mathrm{l}^{-1}$ for the reed bed and $17.7 \mathrm{mg} \mathrm{l}^{-1}$ for the cattail bed, as compared to a mean value of $22.1 \mathrm{mg} \mathrm{l}^{-1}$ for the unvegetated (control) bed. The configuration of Softstem bulrush ( $S$. validus Vahl) and watermifoil ( $M$. verticillatum Linn.) was the best choice for removal of $\mathrm{PO}_{4}^{3-}$ instead of the combination of three aquatic plants mainly because that sometimes in eutrophic situations, the filling in of the waterbody probably results from higher productivity and succession would lead more 
rapidly to the dominance of competitive species, both rooted and floating (Arts 2002; Khan \& Ansari 2005).

\section{CONCLUSION}

The result indicated that aquatic macrophytes configuration mode does impact water quality whereas AFIs with different combination of aquatic plants have different abilities to purify water. Watermifoil (Myriophyllum verticillatum Linn.) is better than yellow-flowered iris (Iris wilsonii) to combine with softstem bulrush (Scirpus validus Vahl) pollutants disposal. The most effective way is the combination of these three aquatic plants. Vegetative characteristics of each type also indicated the trophic condition of the water body promote the growth of plants. The presence of these three plants played a key role in the removal of pollutants, although other plants which are used to confirm AFI configuration is uncertain. So, further experiments are needed to verify the role of different combination of aquatic plants play in water purification. However, the effectiveness of these measures relies heavily on a better knowledge of AFI and aquatic plants, which would be of some support to environmentally friendly restoration in Beijing.

\section{ACKNOWLEDGEMENTS}

This research was supported by the National Key R\&D Program of China (2017YFC0505903) and the Fundamental Research Funds for the Central Universities (2016JX05). Authors would like acknowledge for the constructive comments made by both reviewers and the editors.

\section{REFERENCES}

Arts, G.H. 2002. Deterioration of atlantic soft water macrophyte communities by acidification, eutrophication and alkalinisation. Aquatic Botany 73(4): 373-393.

Bornette, G. \& Puijalon, S. 2011. Response of aquatic plants to abiotic factors: A review. Aquatic Sciences 73(1): 1-14.

Boyd, C.E. 1970. Production, mineral accumulation and pigment concentrations in Typha latifolia and Scirpus americanus. Ecology 51(2): 285-290.

De Stefani, G., Tocchetto, D., Salvat, M. \& Borin, M. 2011. Performance of a floating treatment wetland for in-stream water amelioration in NE Italy. Hydrobiologia 674(1): 157-167.

Denny, P. 1980. Solute movement in submerged angiosperms. Biological Reviews: 55: 65-92.

Dunabin, J.S. \& Bowmer, K.H. 1992. Potential use of constructed wetlands for treatment of industrial wastewaters containing metals. Science of the Total Environment 111(23): $151-168$

Elankumaran, R., Raj, M.B. \& Madhyastha, M.N. 2003. Biosorption of copper from contaminated water by Hydrilla verticillata Casp. and Salvinia sp. Green Pages: Environmental News Sources.

Gersberg, R.M., Elkin, B.V., Lyon, S.R. \& Goldman, C.R. 1986. Role of aquatic plants in wastewater treatment by artificial wetlands. Water Research 20(3): 363-368.
Hu, M.H., Yuan, J.H., Yang, X.E. \& He, Z.L. 2010. Effects of temperature on purification of eutrophic water by floating eco-island system. Acta Ecologica Sinica 30(6): 310-318.

Hunter, R.G., Combs, D.L. \& George, D.B. 2001. Nitrogen, phosphorous, and organic carbon removal in simulated wetland treatment systems. Archives of Environmental Contamination and Toxicology 41(3): 274-281.

James, W.F., Barko, J.W. \& Eakin, H.L. 2004. Impacts of sediment dewatering and rehydration on sediment nitrogen concentration and macrophyte growth. Canadian Journal of Fisheries and Aquatic Sciences 61(4): 538-546.

Jeppesen, E., Sondergaard, M. \& Christofferson, K. 1997. The structuring role of submerged macrophytes in lakes. Ecological Studies 131: 427-441.

Juwarkar, A.S., Oke, B., Juwarkar, A. \& Patnaik, S.M. 1995. Domestic wastewater treatment through constructed wetland in India. Water Science and Technology 32(3): 291-294.

Khan, F.A.\& Ansari, A.A. 2005. Eutrophication: An ecological vision. The Botanical Review 71(4): 449-482.

Lacoul, P. \& Freedman, B. 2006. Relationships between aquatic plants and environmental factors along a steep Himalayan altitudinal gradient. Aquatic Botany 84(1): 3-16.

Madsen, T.V. \& Cedergreen, N. 2002. Sources of nutrients to rooted submerged macrophytes growing in a nutrient-rich stream. Freshwater Biology 47(2): 283-291.

Murphy, K. 2002. Plant communities and plant diversity in softwater lakes of northern Europe. Aquatic Botany 73(4): 287-324.

Nakai, S., Zou, G., Okuda, T., Tsai, T.Y. \& Song, X. 2010. Anti-cyanobacterial allelopathic effects of plants used for artificial floating islands. Allelopathy Journal 26(1): 113-121.

Nakamura, K. \& Mueller, G. 2008. Review of the performance of the artificial floating island as a restoration tool for aquatic environments. World Environmental and Water Resources Congress.

Okia, O. 1993. Characterization of wastewater purification by Cyperus papyrus floating in segmented channel. Thesis, IHE Delft Institute for Water Education. Netherland (Unpublished).

Smolders, A.J.P., Lucassen, E. \& Roelofs, J.G.M. 2002. The isoetid environment: Biogeochemistry and threats. Aquatic Botany 73(4): 325-350.

Stewart, F.M., Mulholland, T., Cunningham, A.B., Kania, B.G. \& Osterlund, M.T. 2008. Floating islands as an alternative to constructed wetlands for treatment of excess nutrients from agricultural and municipal wastes-results of laboratory-scale tests. Land Contamination and Reclamation 16: 25.

Yao, K.K., Song, S.M., Zhang, Z.M., Xu, J., Zhang, R., Liu, J.K., Cheng, L.X. \& Liu, J.L. 2011. Vegetation characteristics and water purification by artificial floating island. African Journal of Biotechnology 10: 19119-19125.

Zhao, F., Xi, S., Yang, X., Li, J., Gu, B. \& He, Z. 2012. Purifying eutrophic river waters with integrated floating island systems. Ecological Engineering 40: 53-60.

Zhu, L., Li, Z. \& Ketola, T. 2011. Biomass accumulations and nutrient uptake of plants cultivated on artificial floating beds in China's rural area. Ecological Engineering 37: 1460-1466.

Hui-Hui Wang, Jing-Lan Liu, Rong Zhang, Jia-Kai Liu, Yu-Qi Zou \& Zhen-Ming Zhang* 
College of Nature Conservation

Beijing Forestry University

Beijing 100083

China

*Corresponding author; email: zhenmingzhang@bjfu.edu.cn
Received: 3 March 2014

Accepted: 25 April 2017 